No. 21/E/KPT/2018, Tanggal 9 Juli 2018

\title{
Penentuan Kadar Protein dan Fraksi Protein Crude Antigen Cysticercus cellulosae dari Isolat Lokal
}

\author{
(DETERMINATION OF PROTEIN CONTENT LEVELS AND FRACTION OF CRUDE \\ PROTEIN ANTIGEN Cysticercus cellulosae FROM LOCAL ISOLATE)
}

\author{
Leksana Aditya Kris Nugraha ${ }^{1 *}$, Ida Ayu Pasti Apsari², Ida Bagus Ngurah Swacita ${ }^{3}$ \\ ${ }^{1}$ Praktisi Dokter Hewan, Jl. Raya Sukowati Km. 2 No. 31, RT01 RW05, Gambiran, Sragen \\ Jawa Tengah, Indonesia 57212; \\ ${ }^{2}$ Laboratorium Parasitologi Fakultas Kedokteran Hewan, Universitas Udayana \\ Jl. PB. Sudirman Denpasar Bali, Indonesia 80225; \\ ${ }^{3}$ Laboratorium Kesehatan Masyarakat Veteriner, Fakultas Kedokteran Hewan, Universitas \\ Udayana. Jl. PB. Sudirman Denpasar Bali, Indonesia 80225. \\ *Email: gutpadel.89@gmail.com; adit.krisnugraha@gmail.com
}

\begin{abstract}
ABSTRAK
Sistiserkosis merupakan penyakit parasitik yang disebabkan oleh larva cacing pita yang disebut Cysticercus. Cysticercus yang ditemukan pada babi adalah Cysticercus cellulosae yang merupakan larva dari cacing pita Taenia solium. Tujuan penelitian ini adalah untuk mengetahui kadar dan fraksi protein Crude antigen C. cellulosae. C. cellulosae yang digunakan adalah isolat lokal yang diperoleh dari babi terinfeksi yang berasal dari Karangasem - Bali. Penentuan kadar protein larva dilakukan dengan menggunakan alat Invitrogen Quibit Fluorometer dan penentuan fraksi protein larva dengan teknik elektroforesis menggunakan SDS-PAGE. Hasil penelitian menunjukan bahwa kadar protein $C$. cellulosae isolat lokal sebesar $867 \mu \mathrm{g} / \mathrm{ml}$. Sedangkan untuk fraksinasi protein larva diperoleh 6 bands protein dengan berat molekul: bands $1=120,5 \mathrm{kDa}$, bands $2=99,8 \mathrm{kDa}$, bands $3=60,8 \mathrm{kDa}$, bands 4 $=47,7 \mathrm{kDa}$, bands $5=35,6 \mathrm{kDa}$, dan bands $6=23,3 \mathrm{kDa}$.
\end{abstract}

Kata kunci: Kadar protein; fraksi protein; Crude antigen; Cysticercus cellulosae isolat lokal.

\section{ABSTRACT}

Cysticercosis is a parasitic disease caused by tapeworm larvae, called Cysticercus. Cysticercus found in pigs is Cysticercus cellulosae which is the larvae of the tapeworm Taenia solium. The purpose of this study was to determine the levels and fractions of Crude protein antigen $C$. cellulosae. $C$. cellulosae used is local isolates obtained from infected pigs originating from Karangasem - Bali. Determination of protein content larvae were performed using an Invitrogen Quibit Fluorometer and determination of protein fractions larvae techniques using SDS-PAGE electrophoresis. The results showed that levels of the protein $C$. cellulosae from local isolate was $867 \mu \mathrm{g} / \mathrm{ml}$. As for protein fractionation obtained 6 bands protein with a molecular weight: bands $1=120.5 \mathrm{kDa}$, bands $2=99.8$ $\mathrm{kDa}$, bands $3=60.8 \mathrm{kDa}$, bands $4=47.7 \mathrm{kDa}$, bands $5=35.6 \mathrm{kDa}$, and bands $6=23.3 \mathrm{kDa}$.

Keywords: Protein level; protein fraction; Crude antigen Cysticercus cellulosae; local isolates.

\section{PENDAHULUAN}

Taeniasis dan sistiserkosis akibat infeksi cacing pita babi Taenia solium merupakan salah satu zoonosis di daerah yang penduduknya banyak mengkonsumsi daging babi dan tingkat sanitasi lingkungannya masih rendah, seperti di Asia Tenggara, India, Afrika Selatan, dan Amerika Latin (Rajshekar et al., 2003;
Swacita et al., 2015). Taeniasis adalah infeksi cacing pita dewasa $T$. solium dalam usus halus manusia, sedangkan infeksi stadium larva atau metacestoda ( $C$. cellulosae) pada inang antara menyebabkan sistiserkosis (Ditjen P3L Depkes R1, 2005). Manusia juga dapat menderita sistiserkosis apabila menelan telur atau proglotida Taenia yang mengkontaminasi makanan atau melalui proses autoinfeksi. Parasit ini 
pada ternak mengakibatkan kerugian ekonomi, karena daging yang terinfeksi tidak layak dikonsumsi dan harus dimusnahkan (EC-HCPDG, 2000). Kejadian penyakit Taeniasis tertinggi di Negara Afrika, Asia Tenggara dan negaranegara di Eropa Timur (Rajshekar et al., 2003). Terdapat tiga provinsi Di Indonesia yang berstatus endemik penyakit taeniasis/sistiserkosis yaitu: Sumatera Utara, Papua dan Bali (Margono et al., 2001; Ito et al., 2002; 2003; 2004). Prevalensi sistiserkosis di Indonesia bervariasi antara $2 \%$ di Bali dan $48 \%$ di Papua. Selanjutnya, Margono et al. (2003) melaporkan bahwa ada sekitar 8,6\% (5/58) dari penduduk lokal di kota Wamena terinfeksi cacing dewasa $T$. solium.

Infeksi sistiserkosis pada babi yang tertinggi juga terjadi di Bali dan Papua. Dilaporkan 70,4\% (50/71) babi positif $T$. solium secara serologi (seropositif) di Papua, dan dinyatakan bahwa babi terinfeksi oleh metasestoda dari $T$. solium (Subahar et al., 2001), demikian juga $10,9 \%$ (7/64) anjing lokal dinyatakan seropositif terhadap sistiserkus dari $T$. solium (Suroso et al., 2006).

Sistiserkosis menimbulkan gejala dan efek yang beragam sesuai dengan lokasi parasit dalam tubuh. Manusia dapat terjangkit satu sampai ratusan sistiserkus di jaringan tubuh yang berbeda-beda. Sistiserkus pada manusia paling sering ditemukan di otak (disebut neurosistiserkosis), mata, otot dan lapisan bawah kulit (Cruz et al., 1999; Kraft, 2007).

Dampak kesehatan yang paling ditakuti dan berbahaya akibat larva cacing Taenia yaitu neurosistiserkosis yang dapat menimbulkan kematian. Neurosistiserkosis adalah infeksi sistem saraf pusat oleh larva T. solium. Neurosistiserkosis merupakan faktor risiko penyebab stroke baik pada manusia yang muda maupun setengah baya, epilepsi dan kelainan pada tengkorak (Cruz et al., 1999).

Penanganan taeniasis/sistiserkosis diperlukan adanya metode yang mudah dan dapat dipercaya secara akurat.
Untuk mencegah penyebaran sistiserkosis dan taeniasis diperlukan pengembangan uji imunodiagnostik untuk mendeteksi keberadaan agen penyakit, terutama dalam hal mendukung diagnosis klinis neurosistiserkosis pada manusia. Beberapa metode serologi yang telah dicobakan untuk mendeteksi adanya sistisercus adalah indirect haemaglutination test (IHA) dan double diffusion agar, immunoelectrophoresis, enzyme-linked immunosorbent assay (ELISA) dan radioimmunoassay (RIA). Di antara metode tersebut, ELISA ternyata merupakan uji yang paling banyak digunakan (Da Silva et al., 2000; Pinto et al., 2000; Husain et al., 2001; Das et al., 2002). ELISA adalah suatu teknik biokimia yang terutama digunakan dalam bidang imunologi untuk mendeteksi adanya antibodi atau antigen dalam suatu sampel. ELISA telah digunakan sebagai alat diagnostik dalam bidang medis, patologi tumbuhan, dan juga berbagai bidang industri (Satria, 2012). ELISA dapat mengevaluasi adanya antigen dan antibodi dalam suatu sampel, karenanya merupakan metode yang sangat berguna untuk menentukan konsentrasi antibodi dalam serum dan juga untuk mendeteksi adanya antigen (Sarmoko, 2011). Metode ini merupakan metode serologi yang paling banyak digunakan mendeteksi sistiserkosis pada manusia dan ternak (Cho et al., 1992; Yong et al., 1993). Teknik tersebut umumnya memberikan hasil yang baik (Cho et al., 1992; Yong et al., 1993). Kordafshari et al. (2010) melaporkan bahwa langkah awal penentuan fraksi protein antigenik dari stadium larva cacing pita sangat penting, baik untuk pengembangan diagnosis maupun vaksinasi. Diagnosis infeksi larva cacing pita, baik pada manusia maupun pada hewan dapat dilakukan dengan pemeriksaan sampel jaringan seperti lidah, pemeriksaan daging pada ternak yang disembelih di rumah potong, biopsi kulit pada manusia dan dengan uji serologi (Kraft, 2007). Uji serologi ditujukan untuk 
melacak adanya antibodi pada serum hewan yang terinfeksi. Uji ini memerlukan kits diagnostik yang harganya relatif mahal. Untuk mengatasi masalah tersebut, maka perlu dilakukan penelitian untuk membuat antigen dari larva cacing pita yang berasal dari isolat lokal yang akan digunakan untuk uji serologi. Langkah awal yang akan dilakukan adalah menyiapkan antigen dari larva cacing pita, menghitung kadar protein dari antigen larva tersebut, dan mempelajari fraksi-fraksi protein yang terdapat pada antigen larva tersebut diperlukan antigen yang cocok agar uji ELISA memberi nilai sensitifitas dan spesifisitas tinggi. Harapan dari penelitian ini ke depannya dapat mengembangkan metode diagnostik yang dipakai mendeteksi sistiserkosis pada hewan hidup menggunakan antigen spesifik yang berasal dari isolat lokal Bali.

Penelitian ini bertujuan untuk mengetahui kadar protein dari crude antigen larva cacing pita yang diperoleh dari isolat lokal, dan fraksi-fraksi protein yang terdapat pada antigen larva tersebut. Diharapkan penelitian ini dapat memberikan informasi lebih lanjut mengenai crude antigen larva cacing pita yang diperoleh dari isolat lokal, sehingga dapat ke depannya dapat digunakan sebagai agen diagnostik untuk menentukan seroprevalensi pada kasus sistiserkosis.

\section{METODE PENELITIAN}

\section{Sampel penelitian}

Sampel yang digunakan dalam penelitian ini adalah larva cacing pita isolat lokal yang diperoleh dari daging babi terinfeksi cacing pita yang berasal dari Karangasem, Bali.

\section{Alat dan bahan penelitian}

Bahan yang digunakan dalam penelitian ini adalah larutan PBS, buffer solution, Quanti ${ }^{\mathrm{TM}}$ Reagen, sodium deodecyl sulfate polyacrylamide gel electrophoresis (SDSPAGE), larutan ammonium persulfat (APS) $10 \%$, buffer disosiasi $1 \mathrm{M}$ yang terdiri atas $5 \mathrm{ml}$ SDS $10 \%$, Tris HCL 1,5 $\mathrm{M} \mathrm{pH} 8,8$, Bromphenol blue, Mecaptoethanol, laemely buffer, kertas isap, stacking gel 4\%, stanning gel 12\%, gliserin, methanol, asam cuka, Tris HCL $0,025 \mathrm{M} / \mathrm{L}$, larutan Tricloroacetic Acid (TCA) $12 \%$, selenium, asam sulfat $\left(\mathrm{H}_{2} \mathrm{SO}_{4}\right)$, asam borat $\left(\mathrm{H}_{3} \mathrm{BO}_{4}\right)$, Methylen Blue (MB), Methylen Red (MR), natrium hidroksida $(\mathrm{NaOH}) 45 \%$, asam khorida ( $\mathrm{HCl}) \quad 0,1 \mathrm{~N}$, larutan pewarna $(50 \%$ methanol, $10 \%$ asam asetat dan $0,06 \%$ comassie blue R-250), buffer sampel (SDS gliserol 50\%, bromphenol blue 0,1\%, tris base, HCL $1 \mathrm{M}$ dan aquades) dan larutan peluntur (5\% methanol dan $7,5 \%$ asam asetat), larutan fiksasi ( $25 \%$ methanol dan $12 \%$ asam asetat), perak nitrat $(0,4 \mathrm{~g}$ $\mathrm{AgNO}_{3}, 70 \mu \mathrm{l}$ formaldehida dan $12 \mathrm{ml}$ aquabides), larutan en hancer $(0,1 \mathrm{~g}$ $\mathrm{N}_{2} \mathrm{~S}_{2} \mathrm{O}_{3} .5 \mathrm{H}_{2} \mathrm{O}$ dan $500 \mathrm{ml}$ aquabides) dan larutan $\quad\left(\begin{array}{llllll}15 & \mathrm{~g} & \mathrm{Na}_{2} \mathrm{CO}_{3} & \text { dan } & 120 & \mu \mathrm{l}\end{array}\right.$ formaldehida) dan etanol (untuk analisis elektroforesis dengan SDS PAGE).

Alat - alat yang digunakan adalah timbangan digital, sentrifius $3000 \mathrm{rpm}$, vortek, alat elektroforesis, pisau, tisu, plastik, talenan, cawan porselin, lumpang (mortir), tabung eppendorf, mikropipet, stirrer, gelas piala, gelas ukur, shakerbath, sisir, alat Quibit Fluorometer.

Daging yang mengandung larva cacing pita dipisahkan antara daging dan larva cacing pita. Larva yang diperoleh dicuci dengan PBS kemudian dimasukkan dalam botol kecil dan disimpan dalam freezer.

\section{Pembuatan crude antigen}

Larva T. solium utuh (berisi cairan dan scolex) ditimbang sebanyak 1 gram. Digerus menggunakan mortir sampai halus. Ditambahkan phosphate buffer saline (PBS), sebanyak $10 \mathrm{ml}$. Disentrifus dengan kecepatan rendah (1000 rpm) selama 3 menit. Supernatannya disedot dan dimasukkan ke dalam beberapa eppendorf. Penentuan kadar protein antigen

Pembuatan buffer working solution (BWS) dengan cara mengambil $800 \mu \mathrm{l}$ buffer solution (BS) dan $4 \mu \mathrm{l}$ Quanti ${ }^{\mathrm{TM}}$ Reagen (796 $\mu \mathrm{l}$ BS $+4 \mu$ Reagen). BWS dimasukan masing-masing $190 \mu \mathrm{l}$ ke dalam 4 eppendorf. Eppendorf I diisi Standar 0 $\mu \mathrm{g} / \mu \mathrm{l}(\mathrm{P} 1)$ sebanyak $10 \mu \mathrm{l}$ demikian pula 
eppendorf II diisi standar $200 \mu \mathrm{g} / \mu \mathrm{l}$ (P2), eppendorf III diisi standar $400 \mu \mathrm{g} / \mu \mathrm{l}$ (P3), dan eppendorf IV diisi crude antigen yang telah diencerkan 100x $(10 \mu$ l antigen $+90 \mu \mathrm{l}$ PBS) sebanyak 10 $\mu 1+190 \mu \mathrm{l}$ BWS). Divortex ke-4 eppendorf selama 2-3 detik. Keempat eppendorf diinkubasi pada suhu ruang selama 2-3 detik. Dilakukan step pembacaan eppendorf (read tube) pada alat fluorometer. Eppendorf yang berisi standar $0 \mu \mathrm{g} / \mu \mathrm{l}$ dimasukan ke dalam fluorometer (tanda bulatan hitam). Kemudian mesin dijalankan sampai muncul kata "complete" dilanjutkan dengan memasukan eppendorf yang berisi standar $200 \mu \mathrm{g} / \mu \mathrm{l}$. Demikian pula untuk eppendorf yang berisi standar $400 \mu \mathrm{g} / \mu \mathrm{l}$. Terakhir dimasukkan eppendorf yang berisi sampel crude antigen cacing pita. Ditekan kata "go". Dibaca hasilnya, kemudian dikalikan dengan faktor pengenceran (100 kali).

\section{Penentuan fraksi protein antigen larva dengan SDS-PAGE elektroforesis}

Teknik pemisahan protein dengan elektroforesis dilakukan dalam tiga tahap. Tiga tahap tersebut adalah ekstrasi protein dari sampel, pembuatan gel menggunakan SDS-PAGE, dan pemisahan protein dengan menggunakan teknik elektroforesis yang dilanjutkan dengan pendeteksian pita-pita atau fraksi-fraksi protein yang terbentuk. Gel yang digunakan adalah gel yang telah terpolimerisasi secara sempurna. Gel yang diperoleh kemudian dipasang, buffer elektroforesis dimasukan dan alat elektroforesis dirangkai. Sebelum dimasukan kedalam sumuran, marker dan sampel ditambah buffer sampel (1:1) dan diinkubasi pada air mendidih selama 1menit. Sampel kemudian dimasukan ke dalam sumur andengan menggunakan mikro pipet sebanyak $10-20 \mu 1$, tergantung tebal tipisnya pitaprotein yang diinginkan. Perangkat elektroforesis dijalankan pada suhu rendah dengan tegangan $100 \mathrm{v}$ dan arus $125 \mathrm{~mA}$ selama 1-1,5 jam hingga bromphenol blue mencapai $1 \mathrm{~cm}$ dari batas gel. Comassie brilian blue dituang ke dalam gel tersebut, kemudian dimasukan ke dalam shaker waterbath dan dijalankan selama 24 jam. Kelebihan warna dibuang dengan merendam gel dalam larutan peluntur sampai diperoleh fraksi-fraksi atau protein-protein yang berwarna biru dengan latar belakang jernih (Laemmli, 1970).

Apabila pita pada gel tidak tampak dengan jelas maka diwarnai dengan silver staining. Gel difiksasi selama 1 jam dengan larutan fiksasi, kemudian dikocok menggunakan shaker waterbath. Setelah 1 jam larutan fiksasi dibuang. Gel selanjutnya ditambahkan larutan 50\% etanol dan dikocok kembali selama 20 menit menggunakan shaker waterbath. Setelah itu larutan etanol 50\% dibuang. Etanol 30\% ditambahkan sebanyak 2 kali selama 20 menit selanjutnya dikocok dan dibuang kembali. Gel ditambahkan dengan larutan en hancer, dikocok selama 1 menit lalu larutan dibuang. Gel tersebut dicuci menggunakan aquabides sebanyak 2 kali selama 20 menit. Gel kemudian dicelupkan dalam larutan antara $15 \mathrm{~g} \mathrm{Na}_{2} \mathrm{CO}_{3}$ dan $120 \mu \mathrm{l}$ formaldehid. Setelah itu, dikocok sampai terlihat pita, kemudian reaksi dihentikan dengan larutan fiksasi (Laemmli, 1970). Pita - pita protein yang tampak pada gel kemudian dihitung berat molekulnya berdasarkan standar (marker) dan hasil perhitungan $R f$.

Pada penelitian ini, hasil perhitungan kadar protein antigen $C$. cellulosae dinyatakan dalam bentuk $\mu \mathrm{g} / \mathrm{ml}$ setelah dibaca dengan alat Invitrogen Quibit Fluorometer kemudian dikalikan dengan faktor pengenceran (100x). Sedangkan fraksi protein crude antigen C. cellulosae, diperoleh setelah dilakukan elektroforesis menggunakan SDS PAGE, dan penentuan berat molekul pita-pita protein (bands) yang muncul dihitung menggunakan rumus $R f$.

$R f=\frac{J P}{J W}$

Ket:

Rf: Berat molekul

JP: Jarak pergerakan pita protein dari tempat awal

JW: Jarak pergerakan warna pelacak dari tempat awal 


\section{HASIL DAN PEMBAHASAN}

Penghitungan kadar protein bertujuan untuk mengetahui kadar protein yang terdapat pada crude antigen C. cellulosae. Pada proses penghitungan menggunakan pengenceran 100x diperoleh kadar protein crude antigen $C$. cellulosae sebesar $876 \mu \mathrm{g} / \mathrm{ml}$. Pada hasil penentuan fraksi protein menggunakan teknik elektroforesis, ditemukan 6 pita (bands) protein yang terlihat pada gel (Gambar 1). Berdasarkan persamaan kurva kalibrasi antara nilai $R f$ dan log berat molekul (BM) marker (Tabel 1) diperoleh persamaan garis regresi logaritma $\mathrm{Y}=(-0.36 \operatorname{Ln}(\mathrm{x})+1,156)$ (Gambar 2).

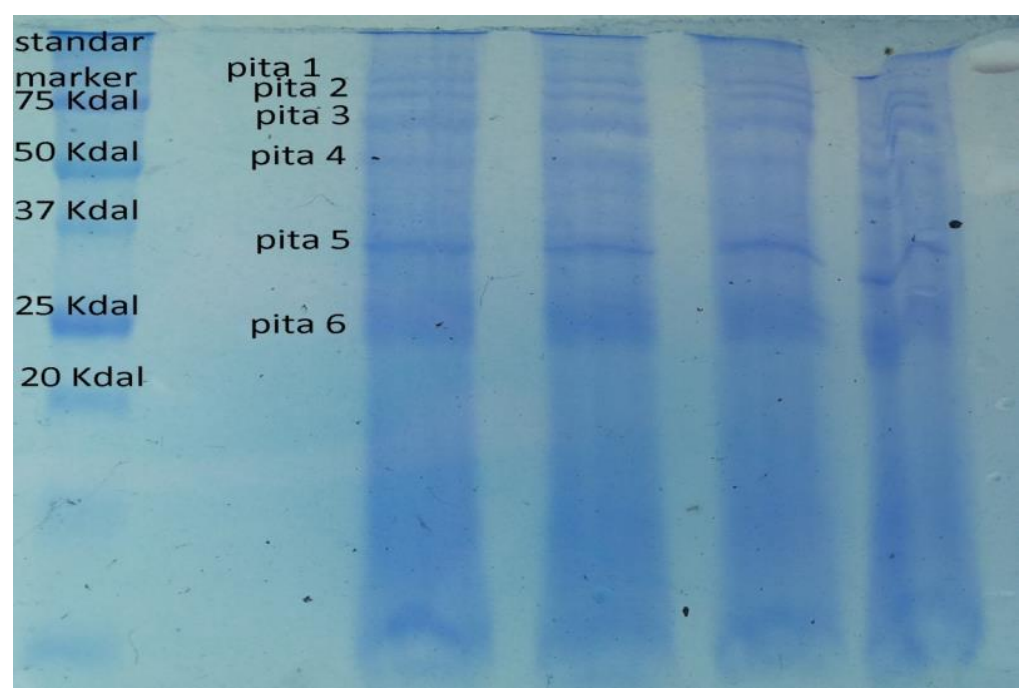

Gambar 1. Bands protein crude antigen C. cellulosae dengan SDS-PAGE.

Tabel 1. Perhitungan berat molekul marker protein menggunakan rumus $R f$

\begin{tabular}{ccccc}
\hline Jarak bands & Marker (pelacak) & $R f$ & $\log$ BM & BM (kDa) \\
\hline 0,7 & 5 & 0,14 & 1,8750 & 75 \\
1,2 & 5 & 0,24 & 1,6989 & 50 \\
1,5 & 5 & 0,30 & 1,5682 & 37 \\
2,8 & 5 & 0,56 & 1,3979 & 25 \\
3,2 & 5 & 0,64 & 1,3010 & 20 \\
\hline
\end{tabular}

Perhitungan berat molekul didapat dari anti-log $\mathrm{Y}$ yang sebelumnya berasal dari nilai $R f$ yang dikonversikan ke dalam persamaan garis regresi logaritma. Berat molekul masing-masing pita protein dihitung menggunakan rumus $R f$, dan hasilnya sebagai berikut: BM pita $1=120,5$ $\mathrm{kDa}, \mathrm{BM}$ pita $2=99,8 \mathrm{kDa}, \mathrm{BM}$ pita $3=$ $60,8 \mathrm{kDa}, \mathrm{BM}$ pita $4=47,7 \mathrm{kDa}, \mathrm{BM}$ pita 5 $=35,6 \mathrm{kDa}$, dan $\mathrm{BM}$ pita $6=23,3 \mathrm{kDa}$ (Tabel 2).

Pada proses penghitungan kadar protein crude antigen $C$. cellulosae, diperoleh sebesar $876 \mu \mathrm{g} / \mathrm{ml}$ menggunakan alat Invitrogen Quibit Fluorometer. Larva $C$. cellulosae yang sudah dipisahkan dari daging digerus seluruhnya, sehingga cairan dan scolex larva digunakan sepenuhnya. Crude antigen C. cellulosae dibuat suspensi $10 \%$, yaitu $10 \mathrm{~g}$ larva digerus dalam mortir kemudian dilarutkan dalam $100 \mathrm{ml}$ PBS. Suspensi 10\% Crude antigen C. cellulosae selanjutnya disentrifus dengan kecepatan 1000 rpm selama lima menit. Supernatan dari suspensi $10 \%$ Crude antigen $C$. cellulosae ini selanjutnya diukur kadar proteinnya dengan alat Invitrogen Quibit Fluorometer. Kadar protein dari bagian supernatan suspensi $10 \%$ ini terlalu besar sehingga tidak dapat terbaca dengan alat 
Invitrogen Quibit Fluorometer. Oleh karena itu, supernatan dari suspensi $10 \%$ ini harus diencerkan terlebih dahulu sampai 100 kali, dan hasilnya diperoleh sebesar $8,76 \mathrm{ug} / \mathrm{ml}$. Jadi kadar protein crude antigen C. cellulosae diperoleh sebesar $876 \mu \mathrm{g} / \mathrm{ml}$. Kadar protein ini berasal dari supernatan suspensi $10 \%$, yang dilarutkan dengan larutan phosphate buffer saline (PBS). Jadi protein larva yang diperoleh adalah protein yang larut dalam PBS. Berbagai bahan pelarut dapat digunakan untuk melarutkan protein larva, antara lain dengan metanol, aseton, alkohol, dan lain-lain. Protein larva yang diperoleh, tentu sangat tergantung dari bahan pelarutnya. Kadar protein larva ini akan lebih besar jika bagian endapannya juga diukur. Berhubung kadar protein yang terdapat pada bagian endapan crude antigen $C$. cellulosae tidak ikut dihitung, maka kadar protein larva yang diperoleh relatif lebih rendah.

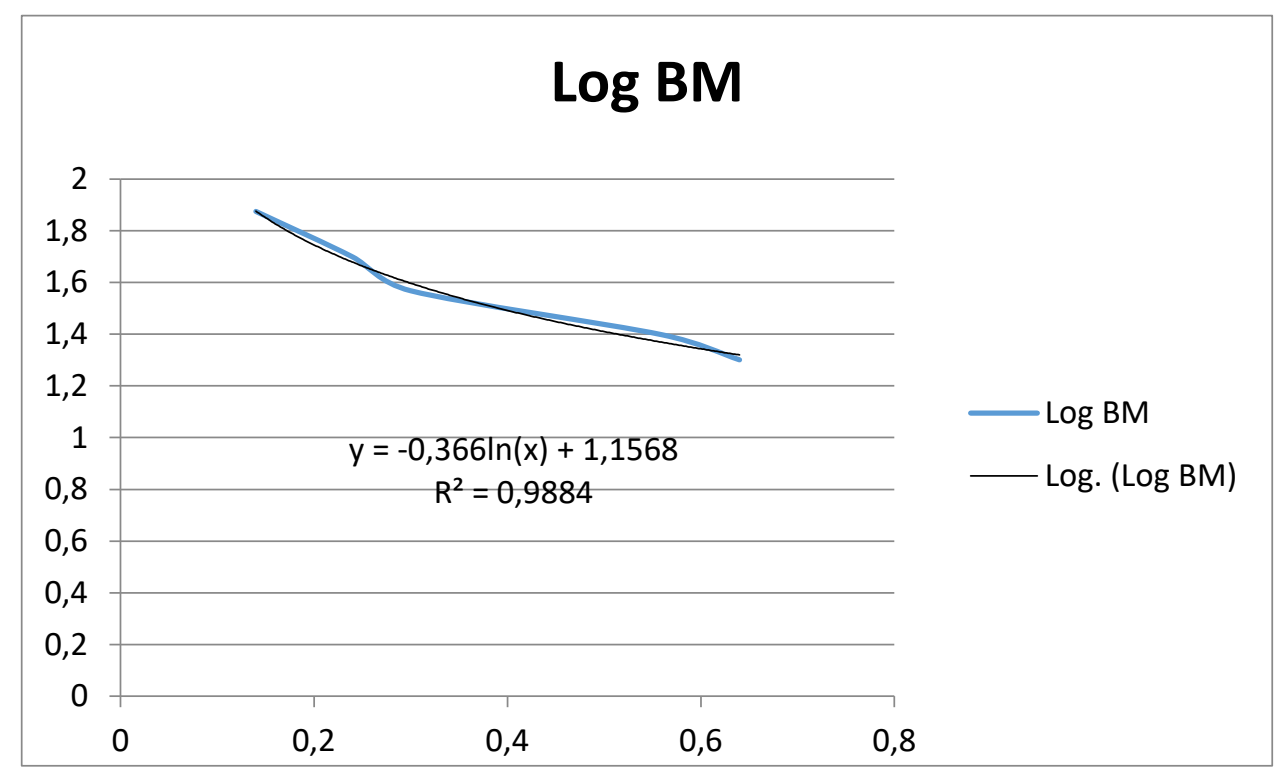

Gambar 2. Persamaan garis regresi logaritma bands protein crude antigen C. cellulosae. Huruf $\mathrm{Y}$ adalah nilai logaritma $\mathrm{BM}$, $\mathrm{x}$ adalah nilai $R f$ yang merupakan hasil dari pembagian jarak pergerakan pita protein dari tempat awal dan jarak pergerakan warna pelacak dari tempat awal.

Tabel 2. Perhitungan berat molekul bands protein crude antigen $C$. cellulosae menggunakan rumus $R f$.

\begin{tabular}{ccccccccc}
\hline $\begin{array}{c}\text { Crude } \\
\text { Ag Cc }\end{array}$ & $\begin{array}{c}\text { Jarak } \\
\text { bands }\end{array}$ & $\begin{array}{c}\text { Marker } \\
\text { (pelacak) }\end{array}$ & $R f$ & Log BM & BM (kDa) & A & B & $\begin{array}{c}\text { Ln } \\
R f(\mathrm{x})\end{array}$ \\
\hline 1 & 0,4 & 5 & 0,08 & 2,0812 & 120,5637 & $-0,366$ & 1,1568 & $-2,5257$ \\
2 & 0,5 & 5 & 0,10 & 1,9995 & 99,8955 & $-0,366$ & 1,1568 & $-2,3025$ \\
3 & 0,9 & 5 & 0,18 & 1,7844 & 60,8718 & $-0,366$ & 1,1568 & $-1,7148$ \\
4 & 1,2 & 5 & 0,24 & 1,6791 & 47,7666 & $-0,366$ & 1,1568 & $-1,4271$ \\
5 & 1,7 & 5 & 0,34 & 1,5516 & 35,6159 & $-0,366$ & 1,1568 & $-1,0788$ \\
6 & 2,8 & 5 & 0,56 & 1,3690 & 23,3891 & $-0,366$ & 1,1568 & -0.5798 \\
\hline
\end{tabular}

Pada proses penentuan fraksi protein menggunakan teknik elektroforesis, menunjukkan terdapat 6 pita (bands) protein yang tampak pada gel. Proses loading antigen ini dilakukan pada 4 lubang sisir dan ternyata diperoleh hasil yang sama. Menurut Cahyarini et al. (2004), perbedaan tebal dan tipisnya pita yang terbentuk disebabkan oleh perbedaan jumlah dari molekul-molekul yang termigrasi, pita tebal merupakan fiksasi dari beberapa pita. Pita yang memiliki kekuatan 
ionik lebih besar akan termigrasi lebih jauh daripada pita yang berkekuatan ionik kecil. Menurut Yunus (2007), protein yang digunakan sebagai ciri genetik untuk mempelajari keragaman individu dalam satu populasi. Ada atau tidaknya pita pada jarak migrasi tertentu menunjukan ada atau tidaknya protein yang termigrasi dan berhenti pada jarak tersebut selama proses elektroforesis. Setelah melihat pola pita protein dilakukan perhitungan berat molekul (BM) pada masing-masing pita dengan rumus $R f$. Hasil elektroforesis pada crude antigen $C$. cellulosae menunjukkan adanya 6 pita (bands) dengan berat molekul (BM) bervariasi dari $23,3 \mathrm{kDa}$ sampai dengan $120.56 \mathrm{kDa}$.

Protein antigen dengan BM bervariasi (10 kDa - $70 \mathrm{kDa})$ ditemukan pada cairan larva (vesicular fluid) dari C. cellulosae dan pada onchosphere (larva) dari cacing pita babi ( $T$. solium) ditemukan protein antigen dengan $\mathrm{BM}$ dari $22 \mathrm{kDa}-70 \mathrm{kDa}$, juga TSOL 18 dan TSOL 45 (Sciutto et al., 2007). Beberapa peneliti melaporkan bahwa terdapat beberapa antigen pada $T$. solium antara lain Antigen B yang sering ditemukan pada pasien neurosistiserkosis (Flisser et al., 1986), merupakan paramyosin dengan sifat mirip dengan fibronectin yang memiliki kemampuan mengorganisir sel-sel yang mengelilingi reaksi radang di sekitar parasite (Laclette $e t$ $a l ., 1989)$. Antigen lainnya yang banyak digunakan dalam imuno-diagnosis adalah beberapa glikoprotein parasit yang mengikat lectil lectin (Tsang et al., 1989) yang disajikan dalam struktur parasit yang kontak dengan inang, serta pada sel radang yang mengelilingi cysticercus tersebut, yang mungkin dapat memodulasi respon imun terkait dari inang (Andriant et al., 1996). Cystisercus juga mengeluarkan sekret antigen ke dalam sirkulasi darah yang sangat potensial mengganggu regulasi sistem imun tubuh yaitu HP10, yang pada awalnya diidentifikasi pada $T$. saginata dan juga ditemukan pada T. solium (Harrison et al., 1989). TSOL 18, adalah antigen onchosphere (larva) dari T. solium dan $T$. saginata (Gauci et al., 1998), yang dapat memberi proteksi tinggi pada babi sehat terhadap ekspos telur cacing $T$. solium dalam suatu percobaan (Flisser el al., 2004).

\section{SIMPULAN}

Berdasarkan hasil penelitian maka dapat disimpulkan bahwa kadar protein dari crude antigen $C$. cellulosae sebesar $876 \mu \mathrm{g} / \mathrm{ml}$ yang mengandung 6 bands protein dengan berat molekul (BM) pada bands $1=120,5 \mathrm{kDa}$, bands $2=99,8 \mathrm{kDa}$, bands $3=60,8 \mathrm{kDa}$, bands $4=47,7 \mathrm{kDa}$, bands $5=35,6 \mathrm{kDa}$, dan bands $6=23,3$ $\mathrm{kDa}$.

\section{SARAN}

Perlu dilakukan penelitian lebih lanjut untuk menentukan bands protein mana yang bersifat antigenik yang dapat digunakan sebagai kandidat vaksin atau sebagai agen diagnostik untuk mendeteksi sistiserkosis pada babi atau pada manusia.

\section{UCAPAN TERIMAKASIH}

Penulis mengucapkan terimakasih banyak kepada Dekan Fakultas Kedokteran Hewan Universitas Udayana serta semua pihak yang telah mendukung pelaksanaan penelitian ini.

\section{DAFTAR PUSTAKA}

Andriant SA, Esterre P, Michault A. 1996. Particularities of the immune response in neurocysticercosis. Arch. Inst. Pasteur. Madagascar. 63: 31-33.

Benitez L, Garate T, Harrison LJ, Kirkham P, Brookes SM, Parkhouse RM. 1996. Cloning and sequencing of the gene encoding the principal $18 \mathrm{kDa}$ secreted antigen of activated onchoephere of Taenia saginata. Mol. Biochem. Parasitol. 78: 265-268.

Cho SY, Kong Y, Kim SI, Kang Y. 1992. Measurement of $150 \mathrm{kDa}$ protein of Taenia solium metacestoda by enzyme-linked immune electrotranfer blot technique. Kor. J. Parasitol. 30(4): 299-307. 
Cruz, ME, Schantz, PM, Cruz I. Preux, PM. Banitez, W. Tsang, VC, Fermoso Dumas, M. 1999. Epilepsi and neurocycercosis in an Andean community. Int. J. Epidemiol. 29: 799803.

Da Silva AD, Quagliato E M, Rossi C L. 2000. A quantitative enzyme-linked immunosorbent assay (ELISA) for the immunodiagnosis of neurocysticercosis using a purified fraction from Taenia solium cysticerci. Diagn. Microbiol. Infec. Dis. 37(2): 87-92.

Das S, Mahajan RC, Ganguly NK, Sawhney IM, Dhawan V, Malla N. 2002. Detection of antigen B of Cysticercus cellulosae in cerebrospinal fluid for the diagnosis of human neurocysticercosis. Trop. Med. Int. Health. 7(1): 53-58.

Ditjen P3L (Pengendalian Penyakit dan Penyehatan Lingkungan). 2005. Manual pemberantasan penyakit menular. Departemen Kesehatan Republik Indonesia. Online http://www.pppl.depkes.go.id/ (Diakses pada 21 Januari 2008).

EC-HCPDG (European Comission-Health Consumer Protection Directorate General). 2000. Opinion of the scientific commite on veterinary measures relating to public health on the control of taeniasis/cysticercosis in man and animals.

Flisser A, Espinoza B, Tovar A, Plancarte, A, Correa D. 1986. Host-parasite relationship in cysticercosis: immunologic study in different compartment of the host. Vet. Parasitol. 20: 95-102.

Flisser A, Gauci CG, Zoli A. 2004. Induction of protection against porcine cysticercosis by vaccination with recombinant onchosphere antigens. Infect. Immun. 72: 5292-5297.

Gauci CG, Flisser A, Ligtowlers MW. 1998. A Taenia solium onchosphere protein homologous to host-protective Taenia ovis and Taenia saginata 18
kDa antigens. Int. J. Parasitol. 28: 757-760.

Handojo I, Margono SS. 2002. Cacing pita yang penting di Indonesia. Dalam: Buku Parasitologi Kedokteran. Ed. 3. Jakarta: Balai Penerbit FKUI. Pp: 9296.

Harrison L J, Joshua, G W, Wright SH, Parkhouse, R.M. 1989. Specific detection of circulating surface/secreted glycoproteins of viable cysticerci in Taenia saginata cysticercosis. Parasite Immunol. 11: 351-370.

Husain N, Jyotsna, Bagchi M, Huasain M, Mishra MK, Gupta S. 2001. Evaluation of Cysticercus fasciolaris antigen for immunodiagnosis of neurocysticercosis. Neurol. India. 49(4): 375-379.

Ito A, Sako Y, Ishikawa Y, Nakao M, Nakaya K, Yamasaki H. 2002. Differential serodiagnosis for alveolar echinococcosis by Em18-immunoblot and Em18-ELISA in Japan and China. In P. Craig and Z. Pawlowski (Eds.) Cestode Zoonoses: Echinococcosis and Cysticercosis - An Emergent and Global Problem. IOS Press. Amsterdam. Pp: 147-155.

Ito A, Nakao M, Wandra T. 2003. Human taeniasis and cysticercosis in Asia. Lancet. 362: 1918-1920.

Ito A, Putra MI, Subahar R, Sato MO, Okamoto M, Sako Y, Nakao M, Yamasaki H, Nakaya K, Craig PS, Margono SS. 2002. Dogs as alternative intermediate hosts of Taenia solium in Papua (Irian Jaya), Indonesia confirmed by highly specific ELISA and immunoblot using native and recombinant antigens and mitochondrial DNA analysis. $J$. Helminthol. 76: 311 - 314.

Ito A, Wandra T, Yamasaki H, Nakao M, Sako Y, Nakaya K, Margono SS, Suroso T, Gauci C, Lightowlers MV. 2004. Cysticercosis/taeniasis in Asia and the Pasific. Vectorborne Zoonotic Dis. 4: 95-107. 
Kordafshari S, Hosseini SH, Mesghi B, Youssefi MR. 2010. Comparison of electrophoretic patternof larval stages of taenidae and determination of specific antigens of hydatid cyst by western blotting. Global Vet. 4(6): 601-606.

Kraft R. 2007. Cysticercosis: An emerging parasitic disease. american family physichican. 76: Online at http://www.aafp.org/ (Diakses pada 21 Januari 2008).

Laclette JP, Rodriguez M, Landa A. 1989. The Coexistence of Taenia solium cysticerci and the pig: role of antigen B. Acta Leiden. 57: 115-122.

Laclette JP, Landa A, Arcos L, Willms K, Davis, AE, Shoemaker C B. 1991. Paramyosin is the Schistosoma mansoni (Trematoda) Homologue of Antigen B from Taenia solium (Cestoda). Mol. Biochem. Parasitol. 44: 287-295.

Margono SS, Ito A, Suroso T. 2000. The problem of taeniasis and cysticercosis in Irian Jaya (Papua), Indonesia. Proc. Of the six Asian-Pasific Congress for Parasitic Zoonoses. Pp. 55-64.

Pinto PS, Vaz AJ, Germano PM, Nakamura PM. 2000. Performance of the ELISA test for swine cysticercosis using antigens of Taenia solium and Taenia crassiceps cysticerci. Vet. Parasitol. 88(1-2): 127-130.

Rajshekar, V, Joshi DD, Doanh NQ, Ven DE, Xiaonong Z. 2003. Taenia solium taeniasis/cysticercosis in Asia: epidemiology, impact and issues. Acia. Trop. 87: 53-60.

Sarmoko. 2011. Tinjauan tentang ELISA. Online at: http://sarmoko31. wordpress.com/2011/06/28/tinjauan tentang-elisa. (Diakses pada Feb 23 2013)

Satria A. 2012. ELISA (Enzyme-Linked Immunosorbent Assay). Program Magister Ilmu Biomedik. Fakultas Kedokteran Universitas Brawijaya; Malang.

Sciutto E, Fragoso G, Fleury A. 2000. Taenia solium disease in humans and pigs: an ancient parasitosis disease rooted in developing countries and emerging as a major health problem of global dimensions. Microbs. Infect. 2: 1875-1890.

Subahar R, Hamid A, Purba W, Wandra T, Karma C, Sako Y, Margono SS, Craig PS, Ito A. 2001. Taenia solium infection in Irian Jaya (West Papua), Indonesia: a pilot serological survey of human and porcine cysticercosis in Jayawijaya District. Trans. $R$. Soc. Trop. Med. Hyg. 95: 388-390.

Swacita IBN, Agustina KK, Polos IW, Fitriani S, Natalia N. 2015. Survei seroprevalensi Taenia solium sistiserkosis di Kabupaten Mimika, Papua. Bul. Vet. Udayana. 7(2): 172178.

Tsang VC, Brand JA, Boyer AE. 1989. An enzyme linked immunoelectro-transfer blot asaay and glycoprotein antigens for diagnosting human cysticercosis (Taenia solium). J. Infect. Dis. 159: 5059.

Wandra T, Ito A, Yamasaki H, Suroso T, Margono SS. 2003. Taenia solium cysticercosis, Irian Jaya, Indonesia. $J$. Emerg. Infect. Dis. 9(7): 884-885.

Yong TS, Yeo IS, Seo JH, Chang JK, Jeong GH. 1993. Serodiagnosis of cysticercosis by ELISA-inhibition test using monoclonal antibodies. Kor. J. Parasitol. 32(2): 149-156. 